\title{
Migration processes and life quality
}

\section{Case of Far Eastern Federal District regions in the Russian Federation}

\author{
Irina Glebova \\ Institute of Management, Economics and Finance \\ Kazan Federal University \\ Kazan, Russian Federation \\ gle-irina@yandex.ru
}

\author{
Alina Khamidulina \\ Institute of Management, Economics and Finance \\ Kazan Federal University \\ Kazan, Russian Federation \\ akhamidulina@gmail.com
}

\begin{abstract}
This article analyses the interconnection of migration processes and life quality on the base of the Far Eastern Federal District of the Russian Federation case. Far East takes the first place in the decrease of the population among the federal districts at the moment, what undoubtedly causes negative consequences in economics and geopolitics. There is a backlog not only in the level of the real monetary income but also in the consumption of the main services which represent the quality of life and migration attractiveness of the Far East. The analysis showed that the main problem of the Far East is related not only to the outflow of population, but first of all, to the lack of population inflow. The population potential of these regions is at the critical level. the doubling of the human resources for the fullscale development of the eastern territories will be needed. However, the current demographic situation and the ongoing migration processes exclude this possibility. The provision of mechanical production of the population of the Far Eastern Federal District must be controlled by the public administration as it is of geopolitical interest.
\end{abstract}

Keywords - migration processes, life quality, region, Russia, demography, Far Eastern Federal District

\section{INTRODUCTION}

The priority goal of any state in many spheres of state and public life is to address urgent socio-economic problems and, as a result, to improve the living standards of citizens through creating conditions for decent work and productive employment, improving the health of the population, and raising real incomes.

In the circumstances, improving the quality of life of the population is a priority for national development in the long term. The main methods of solving the issues of the quality of life are to increase the overall level of social and economic development of the country and the region, as well as the development and implementation of appropriate programs.

The quality of life of the population, of course, is one of the most important social and economic categories. It characterizes not only the essential circumstances of the life of the population, which determine the degree of dignity and freedom of the person of each person, but also speaks about the effectiveness of the current state policy in this or that region.
The great variety of factors influence the development and socio-economic level of any territory including Far Eastern region. These factors are: the geographic position of the region, the amount of natural resources, the level of industrial development, demographic features and many others. The migration of the population, which is the complicated socioeconomic process that is connected with almost all sides of social life directly or indirectly, stands out among these factors.

The inflow and outflow of migrants changes the situation on the job market, determines the infrastructure load, the ecological, sanitary and epidemiological situation, the crime level, and interethnic relations. Migration indicates the socioeconomic attractiveness of the region. The migrants' choice correlates with such objective criteria as the level of income and the grade of poverty in the region, the cost of living, the state of the job market and the quality of the social environment.

Socio-economic transformation of the Russian society has substantially influenced the present migration processes in the Russian Federation as a whole and in the Far Eastern Federal District. The population outflow from the Far East of Russia began with the advent of the market transformations. Far East takes the first place in the decrease of the population among the federal districts at the moment, which undoubtedly causes negative consequences in economics and geopolitics. Negative demographic situation of the Far Eastern Region escalated as along the natural population decline in these years, the absolute population decline is observed.

The goal of the research is the analysis of migration correlation with the life quality of the Far Eastern population in the period of 2005-2015, detection of the problems and the development of recommendations for their solution.

\section{LITERATURE REVIEW}

The topic of the "population life quality" is very relevant and is of great interest for Russian and foreign scientists. One of the most popular life quality indicators is the index of human development. Methodology of the calculation and the level of this index in different countries are presented in the UN reports, in the works of Russian scientists [1,2,3]. There were many publications dedicated to analysis of the individual 
components of the life quality in the last decade. However, the number of works that contain integral evaluation of the life quality is few. Among them one should highlight the works of Kosov [4], Aivozjan [5], Subbeto [6], which are dedicated to the comparative analysis of the population life quality in the Russian Federation subjects.

Publications which authors considered the quality of life of the population in the context of ensuring sustainable development [7] or as an indicator of the socio-economic security of the regions are also of interest [8]. Fassio O., Rollero C. and De Piccoli N. analyzed the interdependence of such indicators as quality of life, health and population density [9]. For such authors as Kotenkova, Vorobjev [10] and Naiden, Motrich, Gritsko [11], the object of the study of the quality of life was not individual regions, but the federal district of the Russian Federation.

In connection with the fact that this study is also devoted to the problems of migration processes, research of Russian scientists in this field is of great interest for the work. Karachurina [12] in her work explores interregional migration and analyzes the reasons for the socio-economic differentiation of space in Russia. Kachalov, Podkorytov, Poluboyarinov [13] call the change in the quality of life as the prerequisite of migration processes. Other Russian scientists [14] come to the same conclusion, and the authors are talking about international migration [15].

\section{METHOD AND CALCULATIONS}

The complex evaluation of the region's population life quality is the complex comparative evaluation of its present state, taking into consideration all conditions and preconditions that influence the life quality of the population in the Russian Federation subject. The evaluation is done by comparing other regions of Russia and the national average background.

The starting point of the implementation of this methodology is the selection of the most significant (key) components of the quality of life, which should be representative of the corresponding basic (private) indicators. These components reflect, on the one hand, persistently acting factors (within a sufficiently long time period) due, for example, to the existing territorial differentiation in the level of development of the most important branches of the social infrastructure, and, on the other hand, regional factors dynamically reacting to the current changes in the current economic situation, including macroeconomic nature or, associated with the changing, priorities of public policy, as well as the amount of funding in the social sphere development of the Russian Federation.

Among the key components of the quality of life of the population in the regions and the most important areas of its integrated assessment, there are:

- income level of the population;

- level of development of the consumer market;

- provision of the population with housing and quality of living conditions;
- provision of the population with basic material goods;

- the level of development of health care and education;

- the state of the environment;

- the state of the labor market.

Each of the above-mentioned components, characterizing the quality of life of the population from a certain point of view, should be considered mandatory in this system. This is due to the exceptional complexity, complexity and multifactoriness of the very concept of "quality of life", the inability to single out one of its main aspects that would act as the defining direction of the state-run regional socially oriented policy for a sufficiently long period.

In the structure of the integrated assessment, it is recommended to use, on the one hand, a sufficient number of factor characteristics - private (basic) representative indicators, combined into seven functional blocks corresponding to the above-mentioned components of the quality of life. And on the other hand, there is the resulting consolidated integral index (index) to assess the quality of life in this or that region as a whole. A characteristic feature of the proposed system of indicators is their unequal quantitative composition across the entirety of the allocated functional blocks. At the same time, each block uses the number of indicators that are actually necessary and sufficient to ensure acceptable reliability of the final estimates for the relevant quality of life component. In the authors' opinion, the proposed content of the selected blocks (groups) of particular indicators characterizes the whole spectrum of the most important components and significant aspects of the quality of life of the population in the context of the subjects of the Russian Federation.

The implemented system of parameters is a balanced list of the most important indicators supported by the regular statistical reporting, which allow the evaluation of the key factors that influence the population life quality in the regions of the Russian Federation.

The index is calculated for each parameter according to (1)

\section{$(X i-X \min ) /(X \max -X \min )$}

The multidirectionality of the chosen local components is taken into consideration for the correct interpretation of the private indexes so for the negatively directed local parameters the opposite values are used (for example the proportion of the poor, death rate etc.) The formula (1) transforms as follows (2)

$(X \max -X i) /(X \max -X \min )$

Seven functional blocks, including 24 private (base) representative indexes are united in the composite (integral) index of the population life quality (Table I) 
TABLE I. Seven functional blocks of the composite index of regions' population life quality

\begin{tabular}{|c|c|c|}
\hline № & Name & Indexes \\
\hline $\begin{array}{l}\text { Block } \\
\text { №1. }\end{array}$ & $\begin{array}{l}\text { Level of the } \\
\text { monetary } \\
\text { income of } \\
\text { population }\end{array}$ & $\begin{array}{l}- \\
\text { per capita; } \\
\text { wage ratio; } \\
\text { propotary income of the population } \\
\text { the income less than the living wage. }\end{array}$ \\
\hline $\begin{array}{l}\text { Block } \\
\text { №2. }\end{array}$ & $\begin{array}{l}\text { Level of the } \\
\text { consumer } \\
\text { market } \\
\text { development }\end{array}$ & $\begin{array}{ll} & \text { retail trade turnover per capita; } \\
- & \text { amount of the paid services per } \\
\text { capita. } & \end{array}$ \\
\hline $\begin{array}{l}\text { Block } \\
\text { №3. }\end{array}$ & $\begin{array}{l}\text { Provision of } \\
\text { the } \\
\text { population } \\
\text { with housing } \\
\text { and quality of } \\
\text { living } \\
\text { conditions }\end{array}$ & $\begin{array}{l}\text { - total area of living quarters per } \\
\text { person; } \\
\text { (consisting of such parameters as relative } \\
\text { density of the total housing area which has 1) } \\
\text { water pipes 2) water drain; 3) heating; 4) gas; } \\
\text { 5) hot water). }\end{array}$ \\
\hline $\begin{array}{l}\text { Block } \\
\text { №4. }\end{array}$ & $\begin{array}{l}\text { Provision of } \\
\text { the } \\
\text { population } \\
\text { with basic } \\
\text { material } \\
\text { goods }\end{array}$ & $\begin{array}{l}\text { - } \\
\text { people; } \\
\text { 100 houmber of the car owners per } 1000 \\
\end{array}$ \\
\hline $\begin{array}{l}\text { Block } \\
\text { №5 }\end{array}$ & $\begin{array}{l}\text { Level of } \\
\text { medicine and } \\
\text { education }\end{array}$ & $\begin{array}{l}\text { provision of the population with } \\
\text { qualified doctors per } 10000 \text { people; } \\
\text { provision of the population with } \\
\text { outpatient and polyclinic organizations; } \\
\text { baby death ratio; } \\
\text { share of qualified personnel in the } \\
\text { total number of employed people in the } \\
\text { economy. }\end{array}$ \\
\hline $\begin{array}{l}\text { Block } \\
\text { №6 }\end{array}$ & $\begin{array}{l}\text { Environmenta } \\
1 \text { conditions }\end{array}$ & $\begin{array}{l}\text { - amount of pollutant emissions per } \\
\text { unit area (consisting of such parameters as 1) } \\
\text { amount of pollutant emissions; 2) amount of } \\
\text { population; } 3 \text { ) the area of the land); } \\
\text { discharge of pollutants into surface } \\
\text { waters per unit of territory, taking into account } \\
\text { the population (consisting of such parameters } \\
\text { as 1) discharge of pollutants into surface } \\
\text { waters; 2) amount of population; 3) area of the } \\
\text { land). }\end{array}$ \\
\hline $\begin{array}{l}\text { Block } \\
\text { №7 }\end{array}$ & $\begin{array}{l}\text { Job market } \\
\text { state }\end{array}$ & $\begin{array}{l}- \text { level of total unemployed } \\
\text { economically active population; } \\
-\quad \text { amount of unemployed who seek } \\
\text { for employment more than } 12 \text { months. }\end{array}$ \\
\hline
\end{tabular}

The composite integral index is calculated out of the average arithmetical indexes. The weight of each block is needed for the calculation.

TABLE II. Block weight

\begin{tabular}{|c|c|}
\hline Block 1 & 2 \\
\hline Block 2 & 1 \\
\hline Block 3 & 1 \\
\hline Block 4 & 1 \\
\hline Block 5 & 1 \\
\hline Block 6 & 0.5 \\
\hline Block 7 & 1 \\
\hline Total & 7.5 \\
\hline
\end{tabular}

The following weight coefficients are received according to conducted survey of pairwise comparison of the importance of these blocks. The results were averaged and inserted into the matrix of pairwise comparisons of T.Saati in accordance with the method of analyzing hierarchies [16].

The composite integral index of the life quality is calculated as the sum of all private indexes with their weight divided by the total sum of the blocks' weight, i.e. 7.5.

Methodological support of a comprehensive assessment of the quality of life of the population in the regions of the Russian Federation includes the use of:

a) the method of integral assessment of the quality of life of the population in the regions of the Russian Federation at the end of the reporting period;

b) the method of grouping the regions of the Russian Federation, depending on the values of integral indicators of the quality of life of the population.

The integral index determined by the proposed method allows one to correctly measure the interregional differentiation of the quality of life in the regions of the Russian Federation, in particular, to position each constituent entity of the Russian Federation in relation to other regions, in relation to the corresponding characteristics in the federal districts of the Russian Federation, and also in relation to the average Russian characteristics quality of life.

To ensure the necessary visualization of the results of a comprehensive (integrated) assessment of the quality of life of the population, a grouping method is used in the regions, the implementation of which involves the development of conditions for the allocation of classification groups of the subjects of the Russian Federation, depending on specific regional values of the integral quality of life index.

For the current stage of socio-economic development, it is proposed to allocate the following five classification groups of regions depending on the value of the integrated assessment of the $\mathrm{i}$-th region in the $\mathrm{t}$-th time period:

Group 1. Leading regions with the highest quality of life of the population $[0.92 ; 1.00)$;

Group 2. Regions with a quality of life of the population above the national average $[0.75 ; 0.92)$;

Group 3. Regions with the quality of life of the population at the average Russian level [0.65; 0.75);

Group 4. Regions with the life quality of the population below the average Russian level $[0.55 ; 0.65)$;

Group 5. Regions with a low quality of life of the population $[0.25 ; 0.55)$; $(<0.25)$.

Group 6. Regions with an extremely low quality of life

It should be noted that the regions of the third group correspond most closely to the Russian standards of quality of life.

The calculations were made in 11-year dynamics from 2005 to 2015 in the five regions of the Far Eastern Federal 
District such as the Republic of Sakha (Yakutia), Primorskiy Krai, Khabarovskiy Krai, Amursk Region, Sakhalin Region.

The analysis of all indexes provided the following data about the regional life quality of the Far Eastern Federal District.

TABLE III. Composite integral index for FEFD for the period of 2005 2015

\begin{tabular}{|c|c|c|c|c|c|}
\hline Year & \multicolumn{5}{|c|}{ Region } \\
\cline { 2 - 6 } & $\begin{array}{c}\text { Republic } \\
\text { of Sakha }\end{array}$ & $\begin{array}{c}\text { Primors } \\
\text { kiy Krai }\end{array}$ & $\begin{array}{c}\text { Khabarovsk } \\
\text { Region }\end{array}$ & $\begin{array}{c}\text { Amursk } \\
\text { Region }\end{array}$ & $\begin{array}{c}\text { Sakhalin } \\
\text { sk } \\
\text { Region }\end{array}$ \\
\hline 2005 & 0.625963 & 0.388873 & 0.676234 & 0.217555 & 0.573818 \\
\hline 2006 & 0.631679 & 0.394750 & 0.644021 & 0.283066 & 0.610213 \\
\hline 2007 & 0.583068 & 0.434053 & 0.579748 & 0.316674 & 0.685444 \\
\hline 2008 & 0.507638 & 0.354577 & 0.473852 & 0.305311 & 0.703352 \\
\hline 2009 & 0.521710 & 0.360719 & 0.458381 & 0.299569 & 0.674947 \\
\hline 2010 & 0.496926 & 0.375327 & 0.473758 & 0.333475 & 0.645196 \\
\hline 2011 & 0.394672 & 0.369674 & 0.537074 & 0.366210 & 0.581678 \\
\hline 2012 & 0.429648 & 0.350828 & 0.537228 & 0.353686 & 0.519111 \\
\hline 2013 & 0.411109 & 0.292956 & 0.524544 & 0.316558 & 0.533315 \\
\hline 2014 & 0.385455 & 0.260091 & 0.532498 & 0.358611 & 0.589129 \\
\hline 2015 & 0.406823 & 0.309020 & 0.560487 & 0.358123 & 0.638502 \\
\hline
\end{tabular}

Let us rank the regions according to the consolidated integral index for 2015.

TABLE IV. Ranking of regions

\begin{tabular}{|l|c|}
\hline Republic of Sakha & 3 \\
\hline Primorskiy Krai & 5 \\
\hline Khabarovskiy Krai & 2 \\
\hline Amursk Region & 4 \\
\hline Sakhalin Region & 1 \\
\hline
\end{tabular}

Visualization of the received data: composite integral index for FEFD for the period of 2005-2015 is demonstrated in Fig.1 below.

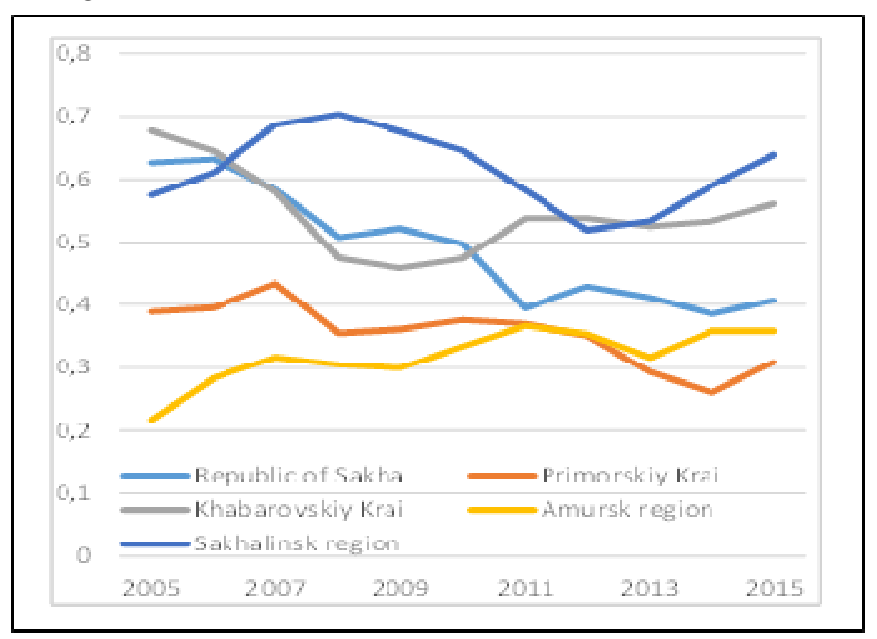

Fig. 1. Composite integral index for FEFD for the period of 2005-2015
Fig. 1 shows the „leading” regions according to the quality of life and the regions with lower rates. However, there is no stable positive growth tendency in any region. Moreover, Yakutia Region which was the "favorite" in the period of 2005-2015 loses its positions and the index of the life quality lowered from 0.62 (Yakutia's peak parameter) to 0.35 (in 2015).

It is evident that the region of the 3rd group of regions with the quality of life at the average Russian level falls to the group of five, the group of people with low life expectancy. The same data for each of the data for 2015 in group 4 (the regions with the quality of life below the average Russian level) include Sakhalin Oblast and Khabarovsk Krai. But Primorsky Krai and Amurskaya Oblast, like Yakutia, are included in the number four, with a certain quality of life that is lower in terms of the average for Russia.

There are no regions in the regions with fewer qualities of life for the eleven leagues considered, which speaks about the outreach and socioeconomic situation of some of the regions of the Far Eastern Federal District. The decrease of the life quality may be explained by instability and changes in Russian economy and in the world economy as a whole.

More than that, in the socioeconomic system in the Far East, they continue to have a number of negative features. They have been determined in the first place by the specific features of the Yakutia East: the yield from the federal market, the rise in fuel prices and transport costs, the growth of tariffs on electricity and heat, and thermal energy. Trends in the growth of real wages and in cash per capita in the region and in the country do not generally coincide, but in the Far East from the beginning of the year, Transport tariffs for rural residents and the inaccessible access of the Far East to the educational and cultural values of Russia, resorts and villages were denied for relatives living in the western regions of the country.

There is a backlog not only in the level of the real monetary income but also in the consumption of the main services which represent the quality of life and migration attractiveness of the Far East. According to the UNESCO pessimistic prognosis, the quantity of the region inhabitants will decrease more than by one third to 4.7 million people (the level of 1959) in 2025. In 2050, if the demographic situation remains at the same level, the amount of population may be almost 4 million people.

In the Far Eastern Federal District as a whole, there is a tendency to improve the quality of life, although a number of regions still occupy low places in the rating. In the ranking of 2016, only three regions occupy places above the 50th. At the same time, three regions occupy positions below the 70th place. At the same time, the rating score increased compared to the previous rating in six of the nine regions of the Far Eastern Federal District. The average value of the rating score of the regions of the Far Eastern Federal District in the rating of 2016 was 38.51 , which is by 0.78 points higher than in the rating of 2015. The calculations of the quality of the life index showed that the corresponding indicators in the Far East in 2005-2015 fall steadily behind the average Russian values and 
the level of development of the region - approximately 1.5 times.

Thus, in the Far Eastern Federal District, there is an urgent need to improve the level and quality of life of the population through measures to regulate the level and quality of life both at the federal and at regional levels. In many respects, the relatively lower standard of living in the Far Eastern District is due to natural and climatic conditions, high cost of living in the region, rather high unemployment, high mortality rates, transport and logistics problems. The Far Eastern Federal District achieved the best results in the field of public health, the ecological situation, the provision of housing for the population and the volume of production of industrial products.

Let us see the demographic indexes of FEFD: birth rates and death rates.

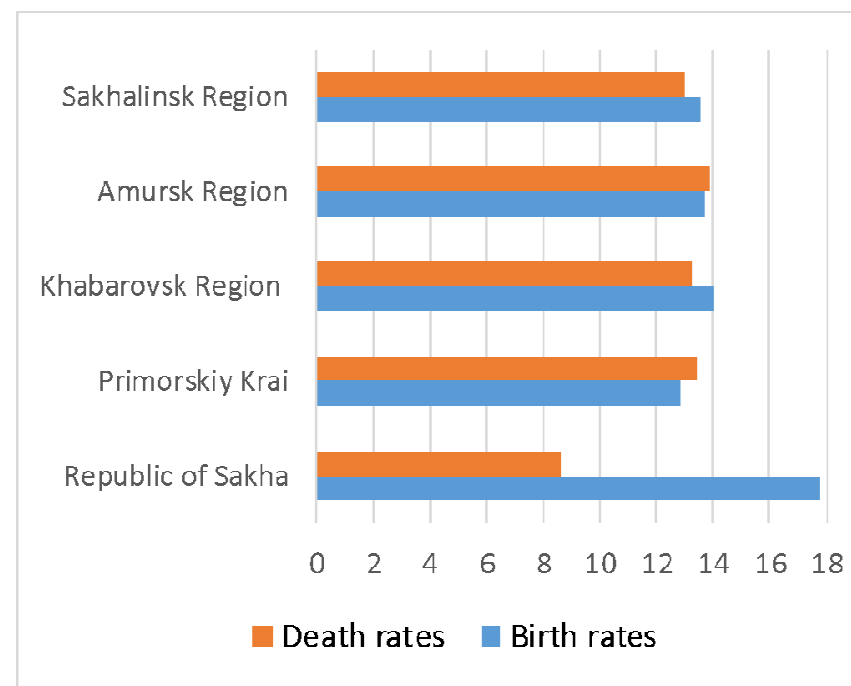

Fig. 2. Demographic indexes of FEFD in 2015

Fig.2 demonstrates that the Republic of Sakha is a leader; it has a stable positive natural population growth rate for 2015, which is $9.2 \%$. Moreover, Sakha is the only region in FEFD where the natural population growth rate has been growing stably for the past 20 years. Amursk region and Primorskiy Krai are the regions with the negative natural population growth ratio (i.e. the death ratio is higher than the birth ratio). The indexes of these regions for 2015 are $-0.2 \%$ and $-0.6 \%$ respectively. However, the death ratio of Khabarovsk Region is very high and the region reaches the positive natural population growth rate only due to its high birth ratio.

TABLE V. The growth rate of migration per 10000 people.

\begin{tabular}{|c|c|c|c|c|c|}
\hline \multirow{2}{*}{ Year } & \multicolumn{5}{|c|}{ Region } \\
\cline { 2 - 6 } & $\begin{array}{c}\text { Republic } \\
\text { of Sakha }\end{array}$ & $\begin{array}{c}\text { Primorskiy } \\
\text { Krai }\end{array}$ & $\begin{array}{c}\text { Khabarovsk } \\
\text { Region }\end{array}$ & $\begin{array}{c}\text { Amursk } \\
\text { Region }\end{array}$ & $\begin{array}{c}\text { Sakhalin } \\
\text { Region }\end{array}$ \\
\hline 2005 & -49 & -23 & -2 & -25 & -56 \\
\hline 2006 & -47 & -22 & -10 & -37 & -58 \\
\hline 2007 & -49 & -17 & 14 & -40 & -27 \\
\hline 2008 & -79 & -7 & 5 & -38 & -56 \\
\hline 2009 & -74 & -10 & 0.4 & -29 & -48 \\
\hline
\end{tabular}

\begin{tabular}{|c|c|c|c|c|c|}
\hline \multirow{2}{*}{ Year } & \multicolumn{5}{|c|}{ Region } \\
\cline { 2 - 6 } & $\begin{array}{c}\text { Republic } \\
\text { of Sakha }\end{array}$ & $\begin{array}{c}\text { Primorskiy } \\
\text { Krai }\end{array}$ & $\begin{array}{c}\text { Khabarovsk } \\
\text { Region }\end{array}$ & $\begin{array}{c}\text { Amursk } \\
\text { Region }\end{array}$ & $\begin{array}{c}\text { Sakhalin } \\
\text { Region }\end{array}$ \\
\hline 2010 & -71 & -35 & -31 & -60 & 63 \\
\hline 2011 & -102 & 6 & 14 & -74 & -4 \\
\hline 2012 & -87 & -6 & -4 & -53 & -31 \\
\hline 2013 & -96 & -37 & -22 & -71 & -44 \\
\hline 2014 & -70 & -20 & -19 & -16 & -59 \\
\hline 2015 & -56 & -14 & -37 & -47 & -27 \\
\hline
\end{tabular}

Table $\mathrm{V}$ demonstrates the rate of migration in the researched regions of the Far Eastern Federal District in dynamics. It is obvious that there has been a stable outflow of the population in the past 11 years. It is connected with the decrease of the industry, cancellation some of the benefits, and the decrease of the life quality of the population in the northern parts of the region. The outflow of the population in the Far East is both from the city and from the countryside. The total decrease of the population may cause the „demographic vacuum” in the Far East. The low mobility of population inside the country is also becomes an extremely crucial issue of Russia's regional development. The problem might have been solved by the mobility of the population, by its flow to the regions and sectors, which provide the highest capitalization of the human resources. Despite the fact that there is a number of economic projects of strategic importance in FEFD, for the past 11 years there was no region with the positive migration balance in the Far East.

Let us s see the influence and dependency of the migration ratio on the life quality in the regions of the Far Eastern Federal District. Let us use the correlation analysis method for that.

TABLE VI. Correlation analysis

\begin{tabular}{|c|c|}
\hline Republic of Sakha & 0.698209739 \\
\hline Primorskiy Krai & 0.165269976 \\
\hline Khabarovskiy Krai & 0.192223478 \\
\hline Amursk Region & -0.19759268 \\
\hline Sakhalinsk Region & 0.032437347 \\
\hline
\end{tabular}

According to the results received, the strongest dependency between the life quality index and migration has the Republic of Sakha (Yakutia). Having the index of 0.698, the quality of life in Yakutia has the direct mild correlation with migration. Sakhalin Region, Primorskiy Krai and Khabarovskiy Krai have direct but weak correlation with this index. Only in Amursk Region, the feedback is seen but it is also weak and insufficient. This feedback means that the quality of life becomes worse with the increase of migration.

Direct but weak dependency (when the life quality grows with the increase of migration) may be explained by the fact that migration is not only the outflow of the population but is also its inflow. During the migration from the central part of Russia, there is the inflow of the capital, qualified staff etc. The demographic problems of Eastern Russia started precisely after the decrease in the number of the people coming to the 
region. Thus for the period of 11 years (2005-2015), the migration has decreased not only in terms of the amount but also in terms of relativity to the remaining level of population. Therefore, the reason for the situation is not the increase of the outflow but also the decrease of the inflow of the population to the region.

\section{CONCLUSION}

The features of social development of the Far East are:

severe climate and nature conditions, which decrease the effectiveness of economy and complicate the vital activity of the population;

poor development of the social infrastructure, especially in the northern part (smaller dwelling space averagely for one inhabitant, the bigger amount of dilapidated and emergency housing, a lower level of housing improvement, poor development of the medicine and education); moreover, the severe climate and nature conditions presuppose higher relative indexes of providing the population with social facilities;

\section{high death rates and low birth rates;}

- the loss of relative advantages at the level of monetary income of the citizens of the eastern regions in comparison with the citizens of the central and western regions of the country and others.

The listed above features of the social development of the Eastern regions of the country indicate that the population potential of these regions is at the critical level. The doubling of the human resources for the full-scale development of the eastern territories will be needed. However, the current demographic situation and the ongoing migration processes exclude this possibility.

In the Far East, the decline in the population is characterized by large monetary incomes and harsh natural conditions. The effectiveness of economy, its specialization and competitiveness depend largely on the natural conditions, economic geography and other geographic factors. The Far Eastern Federal District remains annually a „donor” of migrants for the other regions of the Russian Federation. The migration outflow from the Far Eastern Region is caused by the loss of the comparative advantages of these territories in the Russian economy. Possessing high rates of migration attractiveness, such regions as the Republic of Sakha (Yakutia) and Sakhalin Oblast still lose population primarily due to severe climatic conditions.

The entire history of the development of the Far East is inseparably linked with active state policy, including the population of the area, the most important instrument of which were and are the targeted programs. The provision of mechanical production of the population of the Far Eastern Federal District must be controlled by the public administration as it is of geopolitical interest.

Improving the migration situation in the Far East should be achieved not only by improving the quality of life of the population, but also by paying attention to a number of depressed parts of the region and rural areas. The problem of housing stands alone and its solution may lead to the significant positive changes.

\section{Acknowledgment}

This work was supported by the research grant of Kazan Federal University.

\section{References}

[1] E.E. Zadessenets, G.M. Zarakovsky, I.V. Penova, "Methodology of measuring and assessing the quality of life of the population of Russia", "The World of Measurements", 2/2010. http://www.riastk.ru/mi/adetail.php?ID=37667

[2] O.V. Evdokimova, I.I. Isaev, "Comparative analysis of the methods of quality assessment of life", In the collection: Quality management: problems, research, experience Collection of scientific works. Dedicated to the 105th anniversary of the University of ENGINEER. St. Petersburg State University of Engineering and Economics. St. Petersburg, 2011, pp. $180-187$.

[3] Anand S. and Saint. A. (1994) "Human Development Index: Methodology and Measurement", Occasional Papers, New York: Office for the Compilation of the Human Development Report.

[4] V.V. Kosov, "Quality of life of the population", The World of RussiaVol.10, №2, pp. 50-66, 2001,

[5] S.A.Ayvazyan, "Integral indicators of the quality of life of the population: their construction and use in socio-economic management and interregional comparisons", Moscow: CEMI RAS, 2000, 118 p.

[6] A.I. Subetto, "Quality of life, synthetic revolution in the mechanisms of civilized development and qualitative economics", Standards and quality, 1994, №4, pp. 14-19.

[7] A.G.Leontyeva, A.G. Khokhlov, @Quality management of living in the context of sustainable development of the region", Economy of the region,№ 4, pp. 70-74, 2009.

[8] G.Yu. Gagarin, L.S. Arkhipova, "Quality of life of the population as an indicator of social and economic security of Russian regions", Economics and Entrepreneurship, No. 7 (84), pp. 132-139, 2017.

[9] Fassio O., Rollero C., De Piccoli N., HEALTH, QUALITY OF LIFE AND POPULATION DENSITY: A PRELIMINARY STUDY ON "CONTEXTUALIZED" QUALITY OF LIFE, Social Indicators Research, Vol. 110, № 2, pp. 479-488, 2013.

[10] A.A. Vorobiev, S.N. Kotenkova, "Analysis of the quality of life in the regions of the Volga Federal District of Russia and the possibility of its increase", Kazan economic bulletin, No. 4 (24), pp. 14-22, 2016.

[11] S.N. Naiden, E.L. Motrich, M.A. Gritsko, "Regional monitoring of the quality of life of the population: Khabarovsk Krai and the Far East", Living standards of the population of Russian regions, No. 2 (192), pp. 75-85, 2014.

[12] L.B. Karachurina, "Interregional migration and socio-economic differentiation of modern Russia", Problems of forecasting, № 3, pp. 96115, 2006.

[13] A.P. Kachalov, Yu.A.Podkorytov, V.N. Poluboyarinov, "Predicting population migration as a result of deteriorating quality of life," Strategic stability, № 2, pp. 65-66, 2008.

[14] A.N. Zubets, A.S. Sazanakova, O.S. Zibrova, "International and interregional migration as an indicator of the quality of life of the population". In the collection: Modeling of demographic development and socio-economic efficiency of the implementation of Russia's demographic policy Materials of the international scientific-practical conference. Financial University under the Government of the Russian Federation, Institute for Socio-Political Studies of the Russian Academy of Sciences, 2015, pp. 397-405.

[15] E.I. Polyakova, RA Abramov, I.S. Glebova, "Problem aspects of Russia's migration policy in the sphere of stimulating the return of compatriots". In the collection: State regulation of migration processes and interethnic politics as factors ensuring stability in the modern world: Russian and foreign experience. Collection of abstracts of papers and 
articles of the international scientific and practical conference of Russian and foreign universities and the RGU named after. G.V. Plekhanov with the participation of representatives of state and municipal authorities. FGBOU HPE "RGU them. G.V. Plekhanov," 2015, pp. 166-170.

[16] Saati T. L. Decision-making. Method of the analysis of hierarchies. The economic theory of money, banking and the financial markets [Prinjatie reshenij. Metod analiza ierarhij. Jekonomicheskaja teorija deneg, bankovskogo dela i finansovyh rynkov] / lanes with English R. G.

Vachnadze. Moscow, Radio and communication, 1993, 278 p. 